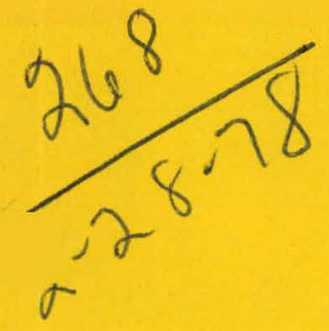

MLM-2489

Acceptable TRU Packaging for Interim

Storage and/or Terminal Isolation:

\section{FY-1977 Final Report}

Jay W. Doty and J. Bruce Peterson

February 17, 1978

\section{MOUND FACILITY}

Miamisburg, Øhio

operated by

MONSANTO RESEARCH CORPORATION a subsidiary of Monsanto Company

for the

U. S. DEPARTMENT OF ENERGY

Contract No. EY-76-C-04-0053 


\section{DISCLAIMER}

This report was prepared as an account of work sponsored by an agency of the United States Government. Neither the United States Government nor any agency Thereof, nor any of their employees, makes any warranty, express or implied, or assumes any legal liability or responsibility for the accuracy, completeness, or usefulness of any information, apparatus, product, or process disclosed, or represents that its use would not infringe privately owned rights. Reference herein to any specific commercial product, process, or service by trade name, trademark, manufacturer, or otherwise does not necessarily constitute or imply its endorsement, recommendation, or favoring by the United States Government or any agency thereof. The views and opinions of authors expressed herein do not necessarily state or reflect those of the United States Government or any agency thereof. 


\section{DISCLAIMER}

Portions of this document may be illegible in electronic image products. Images are produced from the best available original document. 
This report was prepared as an account of work sponsored by the United States Government. Neither the United States nor the United States Department of

Energy, nor any of their employees, nor any of their contractors, subcontractors, or their employees, makes any warranty, express or implied, or assumes any legal liability or responsibility for the accuracy, completeness or usefulness of any in-

formation, apparatus, product or process disclosed, or represents that its use would not infringe privately owned rights.

\section{PRINTED IN THE UNITED STATES OF AMERICA}

Available from

National Technical Information Service

U. S. Department of Commerce

5285 Port Royal Road

Springfield, Virginia 22161

Price: Printed Copy $\$ 4.50$; Microfiche $\$ 3.00$ 


\title{
Acceptable TRU Packaging for İnterim Storage and/or Terminal Isolation: FY-1977 Final Report
}

Jay W. Doty and J. Bruce Peterson

\author{
Issued: February 17, 1978
}

This report was piepored an account of work

sponsored by the United Sittes Government. Neither the

United States nor the United States Department of

Energy, nor any of their employees, nor any of their

contractors, subcontractors, of their employees, makes

any warranty, express or implied, or assumes any lega

liability or responsibility for the accuracy, completeness

or usefulness of any information, apparatus, product or

process disclosed, or represents that its use would no

infringe privately owned rights.

\section{MOUND FACILITY}

Miamisburg, Ohio 45342

operated by

MONSANTO RESEARCH CORPORATION

a subsidiary of Monsanto Company

for the

\section{U. S. DEPARTMENT OF ENERGY}

Contract No. EY-76-C-04-0053 


\section{Contents}

ABSTRACT. . . . . . . . . . . . . . . . . . . . . . . . . . . 3

INTRODUCTION. • • • • • • . . . . • • • . . . . . . . . . . . . . 3

BACKGROUND. • • • . . . . . . . . . . . . . . . . . . . . . . . . . . 3

SURVEY OF CURRENT TRU WASTE STORAGE PROGRAM . . . . . . . . . . • . . . . . 4

CONCEPTUAL TRU WASTE CONTAINER DESIGN SPECIFICATIONS

Philosophy of Specifications . . . . . . . . . . . . . . 6

Conceptual Container Design Specifications . . . . . . . . . . . 7

APPENDIX I: DATA COLLECTION AND ANALYSIS . . . . . . . . . . . . . . 11

APPENDIX II: WASTE PACKAGING MEETING . . . • . • • . . . • • . . . . 23

DISTRIBUTION . . . . . . . . . . . . . . . . . . . . . . . . . 33 


\section{Abstract}

Monsanto Research Corporation, originally funded for FY-1.977-78. by DoE/DWPR, was conducting a program at Mound Facility leading to definition and demonstration of acceptable waste packages for defense transuranic waste for interim storage and terminal isolation. During FY-1977, a Contractor Questionnaire was used to gather pertinent data and to assess contractor concerns. This information was integrated into basic application data in the form. of a checklist. Conceptual Container Design Specifications were developed by analyzing and evaluating: the application data against Federal Regulations and interim/terminal storage constraints.

\section{Introduction}

Monsanto Research Corporation completed a program during FY-1977 at Mound Facility specifying Conceptual Acceptance and Design Criteria for defense transuranic waste packaging for Interim storage and/or Terminal Isolation. A contractor questionnaire was used to gather pertinent data. Site visits were made to formulate an integrated contractor consensus; a packaging meeting was held to examine, discuss, and integrate packaging philosophies; and data collected from these activities and from Task Force meetings were consolidated to provide input to the Basic Application Checklist and Criteria Checklists. Conceptual Design Criteria have now been developed from an analysis and evaluation of the application data against federal regulations and interim/ terminal storage constraints.

\section{Background}

The major objective of DoE Manual Chapter 0511 is responsible technical management of radioactive wastes. With the generation of radioactive waste in DoE operations, this responsibility spans the lifetimes of the radionuclides. close examination of the entire waste management cycle clearly indicates that a totally acceptable waste package containment system is imperative if this objective is to be realized. As presently specified in DoE Manual Chapter 051l-044d(4), solid transuranic waste packaging and storage conditions shall be such that the packages can be readily retrieved in an intact, contamination-free condition for $20 \mathrm{yr}$.

The retrievable storage site for defense transuranic wastes at the Idaho National Engineering Laboratory (INEL)' has been accepting waste since. November, 1970, and has stored this waste in an area designated the Transuranic Storage. Area (TSA). The packaging and storage conditions for the waste stored at the TSA meet the requirements that the containers be readily retrievable in an intact, contamination-free condition for $20 \mathrm{yr}$.

Current Division of Waste Management (DWM) planning indicates continuing use of the retrievable storage areas through FY-1987 with the New Mexico waste Isolation Pilot Plant (WIPP) facility attaining 
full operational status in FY-1988. According to projections, WIPP will begin receiving transuranic wastes in FY-1983. This waste will be stored so that it can be monitored to evaluate the behavior of the waste types under these storage conditions. Projections indicate that the Pilot Plant phase will continue for 3 to $5 \mathrm{yr}$, after which, with retrieval demonstrated and experimentation successfully completed, the pilot plant will be converted to an operational repository for permanent disposal of wastes.

\section{Survey of current TRU waste storage program}

A data collection and review phase involving contractor site plans, federal regulations, and a technical literature search was completed early in the program and provided the project team with all available published data.

A contractor questionnaire was transmitted to appropriate ERDA (DOE) Operations offices and contractors by ERDA (DOE)/ALO in early February 1977, and information received on transuranic waste packaging from solicited contractors was consolidated, evaluated, and reported in Appendix I.

During April 1977, at the request of ERDA (DOE)/ALO, MRC personnel presented the contractor questionnaire data at the TRU Waste Form and Packaging Criteria Meeting at Albuquerque, New Mexico. These data represented current information directly affecting the WIPP Acceptance criteria. MRC provided a mid-term program review at ERDA (DOE) Headquarters on May 9, 1977. This review addressed program progress to date and emphasized data derived from the contractor questionnaire. At that time,
ERDA (DOE)/WPR directed MRC to concentrate efforts to develop Packaging Acceptance Criteria for the Low-Level Transuranic Wastes, because the volume of low-level TRU waste generation for the period FY-1976 and $\mathrm{FY}-1976 \mathrm{~A}$ was $184,144 \mathrm{ft}^{3}$ compared to the 4,856 $\mathrm{ft}^{3}$ of intermediate-level TRU waste generated during the same period.

onsite storage containment systems are of varied configurations, primarily because contractors developed container systems to fit their unique environmental storage requirements. Only $57.58\left(107,542 \mathrm{ft}^{3}\right)$ of the low-level TRU waste generated $(187,144$ $\mathrm{ft}^{3}$ ) was shipped and stored at INEL. These wastes are packaged in containment systems satisfying both DoE Manual 0511 and Interim Storage (INEL) Criteria. A small portion, representing 1.68 of the low-level TRU waste generated $\left(3.034 \mathrm{ft}^{3}\right)$, is shipped to the Nevada Test site for storage. The containment systems for these wastes stored retrievably are different from those used at INEL. The other portion of the waste generated $\left(76,538 \mathrm{ft}^{3}\right)$ is stored onsite by contractor generators.

Accuracy in accounting for the combustible waste volume will affect both the application of future incineration technology as well as the combustion-loading requirement of the WIPP facility during the pilot plant development phase. Therefore, each responding ERDA (DOE) contractor site was visited to ensure understanding of the questionnaire data, investigate significant program concerns, and obtain contractor consensus on TRU waste packaging. Throughout the site visits it was evident that varying levels of compliance with Manual Chapter 0511 exist. This is particularly true with reference to separation of combustible and noncombustible waste materials. Although the questionnaire data received reflect 
that only $21.6 \%$ of the low-level TRU waste generated during FY-1976 and FY-1976A was combustible, a reasonable doubt in the accuracy of this composition must be noted.

An analysis of the information exchanges with the contractors dictates that both a drum configuration and a box geometry (preferably a modular concept) are needed. This analysis and mutual packaging consensus are based on the following contractor requirements and waste generation history:

1. Present Material Handling Systems

2. Current and Future Waste Processing systems

3. Present Material Assay Systems

4. Available Modes of Transportation

5. 718 of the low-level TRU waste generated in FY-1976 and FY-1976A was packaged in box geometry

Cost of any new packaging system is extremely important to the contractors, and their request was that the new system be lower and/or comparable to the present packaging economics. This cost conservation is not only based on future generation of low-level TRU wastes at the contractor sites, but also strongly influenred hy knnwn and planned decontamination and decommissioning projects at Mound, Rocky Flats, LASL, Atomics International, LBL, and Oak Ridge, where substantial increases in low-level TRU wastes are projected.

Repackaging costs will continue to escalate unless containers are defined, proven, and available as soon as possible. Contractor need for a standardized TRU containment system is. immediate. If packaging of TRU wastes continues in nonstandard containment systems, based on the present WIPP Acceptance criteria, the contractors, along, with interim storage sites, will be required to repackage stored wastes prior to placing these wastes in a terminal isolation mode.

Following conversations with contractors generating transuranic waste, a meeting was held at Mound Facility on June 2, 1977, for the specific purpose of discussing proposed criteria for an acceptable TRU waste package for application in both interim storage and terminal isolation. Highlights of the meeting are outlined in Appendix II. At the meeting, contractors and the WIPP representative requested that the project team initiate a survey of container manufacturers to determine whether any commercially available packaging/containers are applicable for the shipment and storage of low-level TRU waste. A brief letter of request was mailed to over 4000 container manufacturers asking for information in the form of container cost that they were currently producing. The form letter survey achieved a variety of interesting results. However, none of the container manufacturers that responded are producing a container which can meet the handling, shipping and storage requirements of TRU radioactive waste materials for terminal isolation.

To ensure that acceptable TRU packaging is developed for defense wastes that is consistent with packaging being developed for commercial wastes, representatives from ORNL Office of Waste Isolation (OWI) visited Mound Facility on May 4, 1977. At the meeting, packaging acceptance criteria, package/containment systems standardication, central procurement, and transportation of the wastes for interim and terminal storage were discussed. The oWI position, at that time, was that 
packaging criteria and TRU packages developed should be conservative and that cost of the packages to users/generators was not important. MRC and OWI agreed that the packaging acceptance criteria should be consistent for both defense and commercial TRU wastes, since both types of generators produce essentially the same types of waste. Common packaging criteria might also relieve commercial users as well as defense contractors from the unenviable position of buying small quantities of unique container systems from several small vendors.

Experience has shown that purchases dealing with small quantities of shipping containers that are nonstandard (nearly stateof-the-art to container manufacturers) are difficult to monitor in terms of vendor quality control and quality assurance programs. The vendor's ability to comply with the vigorous specifications required for radioactive waste packages has proved to be a time consuming and frequently frustrating experience for contractor quality control staffs.

It is extremely important to note that no significant improvement can be made in the quality of low-level waste containers until clearly defined container specifications are developed and until vendors are dealing in large enough quantities of containers. Furthermore, until vendors are enticed with orders large enough to warrant their investment in quality assurance, the risk of substandard containers reaching waste generators will continue to exist. OWI representatives agreed that standardization of both container quality and design specifications would reduce these environmental risks.

At the request of ERDA (DOE)/ALO, Mound representatives attended the Task Force Meeting on WIPP Criteria at ERDA (DOE)/ALO on August 2, 1977. The specific role of Mound personnel was one of providing 'technical information on present packaging systems and their compatability to the WIPP Criteria. Information was supplied to the Task Force as requested during the meeting. Based on the combustibility and radiolysis requirements as written in the WIPP Acceptance Criteria, it was concluded that present TRU packaging does not meet the criteria for all types of wastes. In the final report of the Task Force on the WIPP Interrelationship, a recommendation was made that a standardized container system designed to optimize space, provide fire barrier, and limit gas generation during storage should be developed. The Acceptance Criteria for TRU Waste Packaging for Interim and/or Terminal Isolation developed through this program are directed toward accomplishing this recommendation.

\section{Conceptual TRU Waste Con- tainer Design Specifications}

\section{Philosophy of Specifications}

More than 16 different packaging configurations are being used for interim storage of TRU wastes. The acceptability of these configurations for direct shipment and isolation in the WIPP is still in question. The proliferation of waste packages currently in use is a direct result of efforts of the waste generators to package their unique TRU wastes into containers able to meet the 20-yr retrievability requirements under the differing environmental conditions of onsite storage. An attempt to carry through the responsibility of conceptual design of a family of standardized TRU waste containers will be difficult without established parameters with regard to waste form and interim storage 
environment. In the selection of materials for construction of a particular packaging system, it is important first to consider the characteristics of the system, giving special attention to extraneous factors that may influence decomposition. Since these factors would be peculiar to a particular system, it may be impractical to offer hard and fast rules that would cover all situations. As stated in one of the Sandia early rough drafts of TRU Waste Acceptance Criteria, "It (conceptual design criteria) is in no sense an attempt at unilateral rulemaking." However, through Mound's study of TRU waste packaging and resulting comparisons of the Basic Application Checklist (shown in Appendix I, Tables 17 and 18) to the transportation and isolation requirements, a set of conceptual design specifications was assembled for the waste container which is defined as follows:

\section{WASTE CONTAINER}

The box or drum, including any associated liner and/or shielding material, that immediately surrounds. (and is considered to be an integral, disposable part of). the waste material.

\section{Conceptual Container Design}

\section{Specifications}

\section{STRUCTURAL DESIGN}

The structural design of all low-level TRU waste containers must meet the minimum requirements of a Type A package as outlined in 49CFR17.3.398b. Low-level TRU waste is any solid waste material, other than high-level waste, which i,s contaminated with long-lived alpha emitters to the extent that, under the provisions of
DoE Manual Chapter 0511, is not suitable for surface burial, but which exhibits sufficiently low radiation levels $(\leq 500$ mrem/hr) that it is amenable to handling by. "contact" methods. This minimum structural. design requirement shall be required for all TRU waste packages to assure safety to personnel during handling, loading, and unloading operations. During shipment, the Type A containers may be placed inside a reusable Type "B" overpack. The Type "B" container must meet more rigorous structural design requirements and tests than Type A containers to provide for maximum safety during shipment. Cost effective packaging and transportation of TRU waste materials will require the single use Type A packages to be relatively inexpensive but capable of meeting the requirements of contamination control from the time the containers are filled until they are backfilled inside the WIPP facility.

\section{DESIGN LIFE (Decomposition)}

The design life of all TRU low-level waste containers for contamination-free retrieval shall be 10 yr minimum when stored in a noncorrosive atmosphere $(\mathrm{pH}$ $7-8), 608$ relative humidity, and $100^{\circ} \mathrm{F}$. The design life parameters may suggest a change in DoE Manual 0511 from 20-yr intact contamination-free retrievability to a 10-yr intact contamination-free retrievability concept. Life of the shipping container will start from the time the container is manufactured until backfilled in the WIPP. The 10-yr life is based upon the forecast that the WIPP will be fully operational for TRU waste containers in 1988. Life cycle of the container will include manufacturing, delivery, storage, transmittal into the WIPP, analysis, and backfilling. This life 
cycle should be approximately 5 yr; however, it could approach 10 yr because the backlog of interim stored wastes will be in direct competition with freshly packaged waste for isolation space in the Isolation Facility. All filled waste containers must be protected from environmental conditions that could significantIy reduce the design life of the waste containers to less than $10 \mathrm{yr}$.

\section{MATERIALS OF CONSTRUCTION}

Materials of construction shall be based on design life and structural design requirements. Ferrous and nonferrous metals, plastics, reinforced plastics, fiberboard, corrugated fibers, wood, and concrete have been considered for container materials. All these materials can meet the requirements for hazardous materials transportation and are acceptable in the WIPP in limited quantities. Therefore, the choice of materials, or combinations thereof, can be made from the above group. However, choice will be influenced by the waste form, container design, economics, . and, most important, final WIPP TRU Waste Acceptance Criteria.

\section{MAXIMUM WEIGHT OF CONTAINER AND CONTENTS}

The weight of a single container filled to $98 \%$ capacity is limited to $25,000 \mathrm{lb}$ $(11,400 \mathrm{~kg})$ based on a contents density of $125 \mathrm{lb} / \mathrm{ft}^{3}\left(2000 \mathrm{~kg} / \mathrm{m}^{3}\right)$. This design weight is based on the $25,0001 \mathrm{~b}(11,400$ $\mathrm{kg}$ ) maximum capacity of the WIPP lowlevel hoist cage.

\section{SHAPE}

The container family shall be modular, having a shape which will provide maximum packing efficiency in storage. The cylindrical container has a packing efficiency of 20.69 and the void space will be $31 \mathrm{ft}^{3}$ for every $100 \mathrm{ft}^{3}$ of waste in terminalisolation. The cylindrical container, up to $8 \mathrm{ft}^{3}$, is readily mass produced and available in metal, plastic, and fiberboard: However, because of the underground location for isolation of TRU wastes, emphásis must be placed on container shape with higher packing efficiencies for the waste materials.

\section{D.IMENSIONS}

Waste cöntainer dimensions shall be based on the criteria given in Table 1 to provide flexibility in mode of transportation.

\section{HANDLING APPURTENÄCES}

All low-level TRU waste containers must be provided with cleats, offsets, or chimes which permit handing by fork lift.

\section{SECURITY SEAL}

The outside of each waste container must incorporate a feature such as a seal that is not readily breakable and that, while intact, will be evidence that the package has not been illicitly opened.

\section{$\cos \mathrm{T}$}

Current low-level waste packages which can meet the requirements of DOE Manual Chapter 0511, WIPP, and DOT Type A have costs ranging from $\$ 3.57 / \mathrm{ft}^{3}(4 \times 4 \times 7$ ft fiberglass reinforced polyester resin box) to $\$ 18.19 / \mathrm{ft}^{3}$ (DOT $17 \mathrm{H}, 55-\mathrm{gal}$, stainless steel drum) for the packaging materials: Cost per cubic foot of storage volume for the standardized container family should be toward the lower end of this range to be cost effective. 


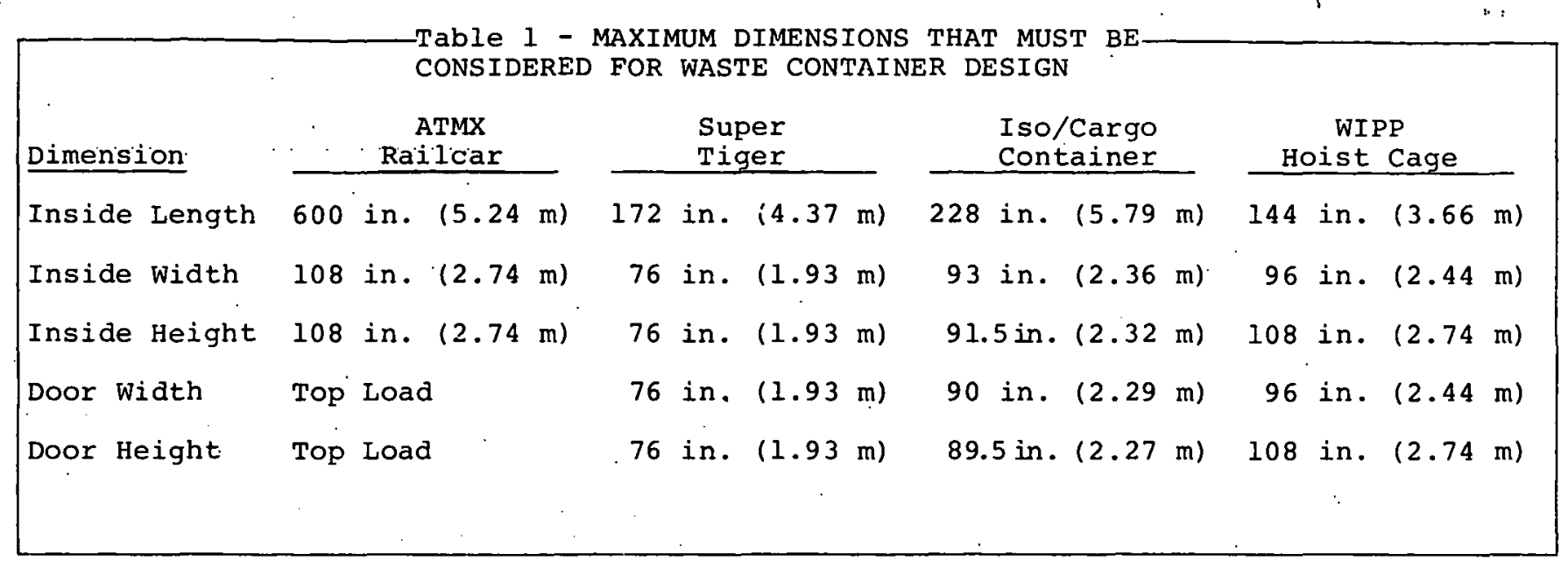


THIS PAGE

\section{WAS INTENTIONALLY LEFT BLANK}


Appendix I

Data collection and analysis 


\section{Contractor questionnaire}

The contractor questionnaire was transmitted to appropriate operations offices and contractors by ERDA/ALO in early February, 1977. The participating con-" tractors whose data has been extracted and consolidated into this report are shown in Table 1 .

Of the total low-level TRU waste generated during FY-1976A, significant differences in waste volume generation are noted at each site as illustrated in Table 2 .

The TRU isotopes associated with the lowlevel waste are shown in Table 3 . The predominant isotopes are, of course, plutonium-238 and plutonium-239. Other isotopes were reported in trace quantities; however, they are reported in the lowlevel waste volumes as required by ERDAM 0511 .

As noted in Table 2 , the contractors reported a total low-level TRU waste generation volume of $187,144 \mathrm{ft}^{3}$ for the period FY-1976 and FY-1976A. However, of that total volume, only $21.6 \%$ of this waste is categorized as combustible (hydrogenous) TRU waste. It would appear at this time, based on this composite information, that 78.4\% of the low-level TRU waste generated in the FY-1976, 1976A period, is not combustible waste and would meet the present WIPP Acceptance Criteria dated June 17, 1977 .

The transportation of the low-level TRU waste generated in FY-1976, 1976A is heavily dependent upon the ATMX railcar.
Table 1 - THE FOLLOWING CONTRACTORS HAVE RETURNED THEIR TRU WASTE PACKAGING QUESTIONNAIRES TO MRC

$\begin{array}{ll}\text { AI } & \text { LASI } \\ \text { ANL-E } & \text { LBL } \\ \text { ANL-W } & \text { LLL } \\ \text { BMI } & \text { MRC } \\ \text { ARCHO } & \text { RI } \\ \text { EG\&G } & \text { SRP } \\ \text { ORNL } & \end{array}$

Table 2 - THE LOW-LEVEL TRU NASTEVOLUME VARIES SIGNIFICAIJTLY BETINEEN CONTRACTOR SITES

\begin{tabular}{lr} 
Contractors & Volume $\left(\mathrm{ft}^{3}\right)$ \\
\cline { 2 - 2 } RI & 89,262 \\
ARCHO & 53,988 \\
MRC & 13,286 \\
LASL & 11,700 \\
SRP & 7,000 \\
ANL-E & 4,700 \\
ORNL & 3,850 \\
LLL & 2,535 \\
LBL & 395 \\
BMI & $: 287$ \\
AI & 1.34 \\
EG\&G & 7,144
\end{tabular}

Table 3 - THE ISOTOPES BELOW ARE BEING GENERATED IN LOWLEVEL TRU DEFENSE WASTE

plutoniun - 238, 239, 240,241, 242

curium - 244

californium - 252

berkelium - 249

uranium - 233

americium - 241, 213

neptunium - 237 
As shown in Table 4, of the total 187,144 $\mathrm{ft}^{3}$ of low-level TRU waste generated, 57.58 of the waste is stored at INEL $(107,542$ $\left.\mathrm{ft}^{3}\right), 40.9 \%$ of the waste is stored by contractors onsite, $\left(76,538 \mathrm{ft}^{3}\right)$, and $1.6 \%$ of the waste is stored at NTS $\left(3,064 \mathrm{ft}^{3}\right)$. one interesting and important observation obtained from the data was the large amount of low-level TRU waste generated during this period and stored onsite. One question becomes quite apparent: "If this onsite stored waste had to be shipped, could the present transport systems accommodate the increased volumes?"

The data received also support the fact that 718 of the low-level TRU waste generated in FY-1976, 1976A was packaged in a box geometry as shown in Table 5. Regarding drums, it was noted that $48,500 \mathrm{ft}^{3}$ of waste is contained in 55-gallon drums. However, only $28,300 \mathrm{ft}^{3}$ of the low-level TRU waste was contained in a DOT 17C drum with a high-density polyethylene (HDPE) liner. Approximately 14,500 $\mathrm{ft}^{3}$ of waste was packaged in a DOT $17 \mathrm{C}$ drum, and the remaining portion of the waste was packaged i.n DOT $17 \mathrm{H}$ drums. A small volume (800 $\mathrm{ft}^{3}$ ) of low-level TRU waste was also packaged in DOT $17 \mathrm{H} 30$-galion drums.

In Table 6, the $5 Y=1976$, 1976A low-level TRII waste generation by type is shown. The equipment and glovebox/laboratory waste types comprise approximately $65 \%$ of the TRU waste volume generated. Waste type categories were developed by consolidation of definitions supplied by the participating contractors. The lowlevel TRU waste type definitions are listed in Table 7 .

The physical and chemical properties of low-level TRU waste types, physical forms, and hazardous properties are shown in

\begin{tabular}{|lr|}
\hline Table 4 - TRANSPORTATION OF THE- \\
LOW-LEVEL TRU WASTE IS HEAVILY \\
DEPENDENT ON THE ATMX RAILCAR \\
\\
Poly Panther (truck) & $4,740 \mathrm{ft}^{3}$ \\
Supertiger (truck) & $3,351 \mathrm{ft}^{3}$ \\
ATMX Railcar & $100,508 \mathrm{ft}^{3}$ \\
\hline
\end{tabular}

Table 5 - SEVENTY-ONE PERCENT OFTHE LOW-LEVEL TRU WASTE IS CURRENTLY PACKAGED IN A BOX GEOMETRY

\section{5-gallon Drums}

DOT $17 \mathrm{H}$

DOT $17 \mathrm{C}$

DOT 17C/HDPE Liner

\section{Boxes}

FRP

Steel

\section{Others}

Corrugated Metal Pipe

30-gallon Drums

$$
\begin{aligned}
& 5,750 \mathrm{ft}^{3} \\
& 14,500 \mathrm{ft}^{3} \\
& 28,300 \mathrm{ft}^{3}
\end{aligned}
$$

$$
125,100 \mathrm{ft}^{3}
$$$$
8,200 \mathrm{ft}^{3}
$$

$$
4,500 \mathrm{ft}^{3}
$$$$
800 \mathrm{ft}^{3}
$$

\begin{tabular}{|lr|}
\hline Table 6 - THE FY-1976, 1976A- \\
\hline & \multicolumn{1}{|c|}{$\mathrm{Ft}^{3}$} \\
Waste Type & 81,568 \\
Equipment & 40,438 \\
Combustibles & 39,785 \\
Glovebox/Laboratory & 10,765 \\
Cemented Wastes & 7,832 \\
Dry Sludges & 6,697 \\
Absorbed Liquids & 59 \\
Others & \\
\hline
\end{tabular}

Table 8. From the abstracted data, no major chemical or physical problems exist, and no hazards are foreseen in the packaged low-level TRU waste generated by the surveyed contracturs. 
Equipment:

Combustibles :

Glovebox/Laboratory :

Cemented wastes:

Dry sludges:

Absorbed Liquids:

others:
Decommissioned gloveboxes., equipment replacements, process tankage, machine tools, refractories, building rubble, ductwork, metal piping.

Paper, rags, clothing, fabric, tissves, rubber gloves and tubing, wood, manipulator boots; plastics, resins.

Process hardware, metal, glass, ceramics, small process equipment, instrumentation sources, graphite, refractories, asbestos- HEPA filters, tools.

oils, caustics, neutralized solutions, organics, and sludges mixed directly with Portland Cement and/or a mixture of Portland Cement and. Vermiculite.

Process sludge resulting from treatment of aqueous waste solutions by carrier hydroxide precipitation; followed by clarification, dewatering with rotary vacuum filtration and drying.

Acid and caustic solution, both neutralized and unneutralized, orgainc solutions and oils, "absorbed on diatiomaceous earth, bentonite clay, and calcium silicate.

Contaminated soil.
Each waste category shown in Table 6 was expanded into greater detail as shown in Tables 9 through 15 . The data represented in these Tables provide information on the generating agency, isotope, volume of generated waste, average concentration per package, storage, and transportation aata.

\section{Technical program meetings}

Two meetings were sponsored by Mound Laboratory as part of our objective of achieving low-level TRU waste generator concensus on the TRU waste package acceptance criteria.

On May 4, 1977, Doug Turner and Bill Peachin of the Office of Waste Isolation visited Mound for a mutual exchange of information in relation to ERDA and Commercial TRQU $\because$.
Low-Level wastes. . The meeting was informative, and from the discussions the following.list of areas of mutual interest and concern was completed:

1) Comparable TRU low-level and intermediate level package acceptance criteria for ERDA and commerical.

2.) The immediate need to develop and $\therefore$... fabricate.a new transport system $\therefore$ for low and intermediate TRU waste.

3) Desirability of implanting a control. procurement policy for quality assured waste containers for both ERDA and commercial wastes. 
Table 8 - PHYSICAL AND CHEMICAL PROPERTIES AND

HAZARDS ASSOCIATED WITH LOW-LEVEL TRU WASTE I'YPES

Waste Type

Equipment

Combustibles

Glovebox/Laboratory

Cemented Wastes

Dry sludges

Absorbed Liquids
Physical

Dry Solid Form Noncombustible

Dry Solid Form Combustible

Dry solid Form Noncombustible

Solidified Liquid Noncombustible

Dry Solid Form Noncombustible

Absorbed Liquids

$$
\begin{aligned}
& \text { Chemical } \cdots " \because \text { Hazards }
\end{aligned}
$$

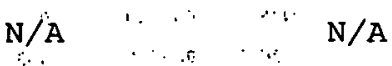

Hydrogeneous . N N A

$\mathrm{N} / \mathrm{A} \quad \cdots \mathrm{N} / \mathrm{A}$

Acidic $\cdot \cdots, N / A$

Caústic

Hydrogeneous

Caustic

$\mathrm{N} / \mathrm{A}$

Acidic

Cáustic

organic oxidizing Reducing

Table 9 - LOW-LEVEL TRU WASTE WASTE CATEGORY - EQUIPMENT

\begin{tabular}{|c|c|c|c|c|c|c|c|c|c|c|}
\hline Agency & Isotope & $\mathrm{ft}^{3}$ & Waste & & storage & & & & Transpor & \\
\hline & & & $(n C 1 / g)$ & INEL & Onsite & NTS & $\overline{\mathrm{ATMX}}$ & VAN & Supertiger & Polypanther \\
\hline ARHCO & Pu-239 & 43,368 & 325 & & $\mathrm{x}$ & & & & & \\
\hline$R I$ & $\mathrm{Pu}-239$ & 32,500 & 35,000 & $\mathbf{x}$. & & . & $\mathbf{x}$ & & 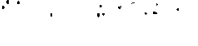 & \\
\hline LASL & Pu-239 & 2,000 & 600 & & $\mathbf{x}$ & & & & $\therefore:$ & \\
\hline MRC & $\mathrm{Pu}-238$ & 200 & $<100$ & $x$ & & . & & $\mathrm{x}$ & . & \\
\hline MRC & $P u-238$ & $1 ; 500$ & 700,000 & $\mathbf{x}$ & & & $x$ & & & \\
\hline SRP & $P u-239$ & $\frac{2,000}{81,568}$ & 5,000 & & $\mathrm{x}$ & & & . & $\cdot$ & . \\
\hline
\end{tabular}

1. Percent of total waste 43.588 equipment in total waste volume

2. Isotope percentage $\mathrm{Pu}-239$ (988) $\mathrm{Pu}-238$ (28)

3. Average Content per package Pu-239 (325-10,000 nCi/g waste) Pu-238 ( $100-700,000 \mathrm{nCi} / \mathrm{g}$ waste)

4. Storage distribution INEL (41:98) "Onsite (58.18)

5. Transport system ATMX (41.78) Vạ (0.28) 


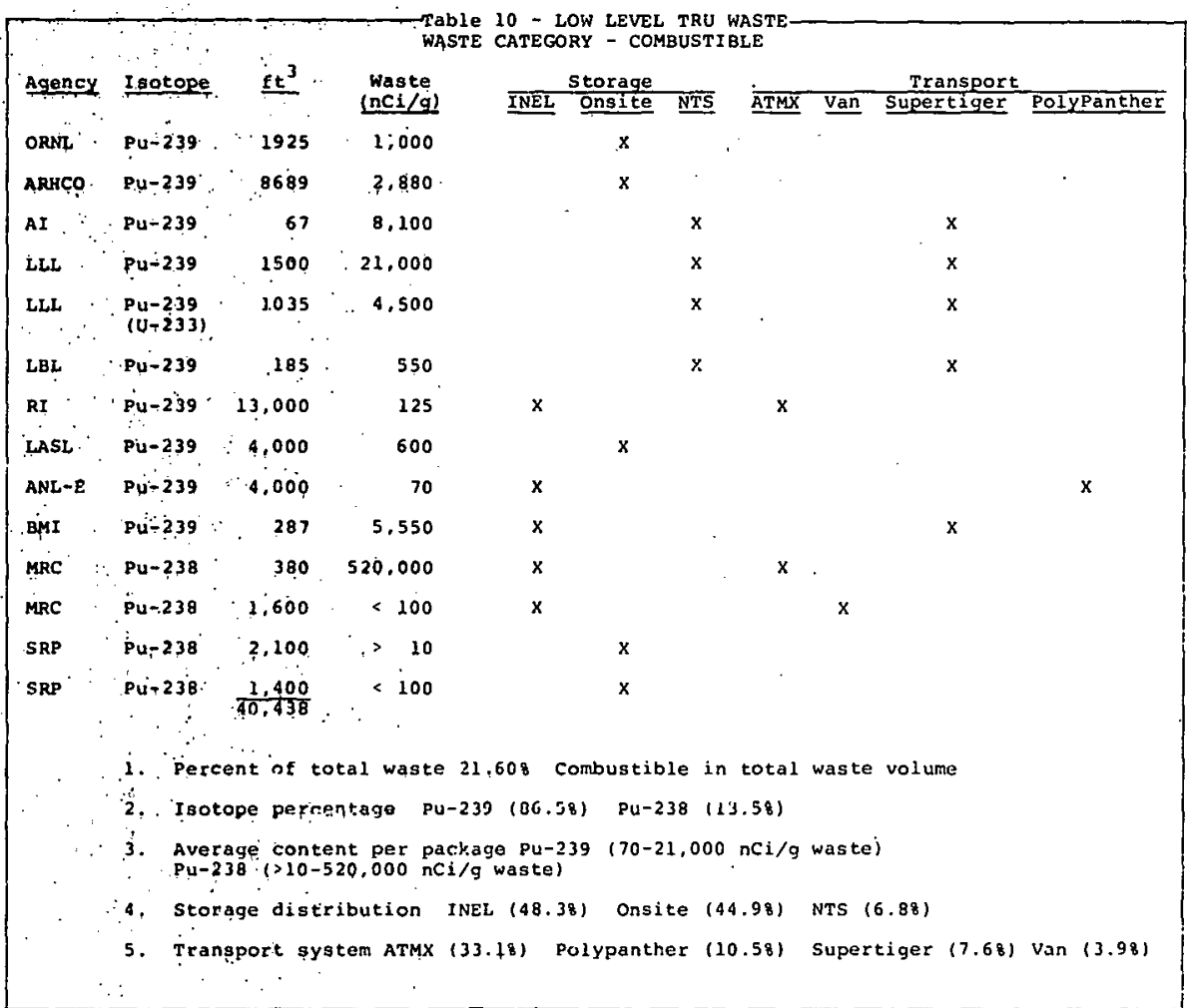




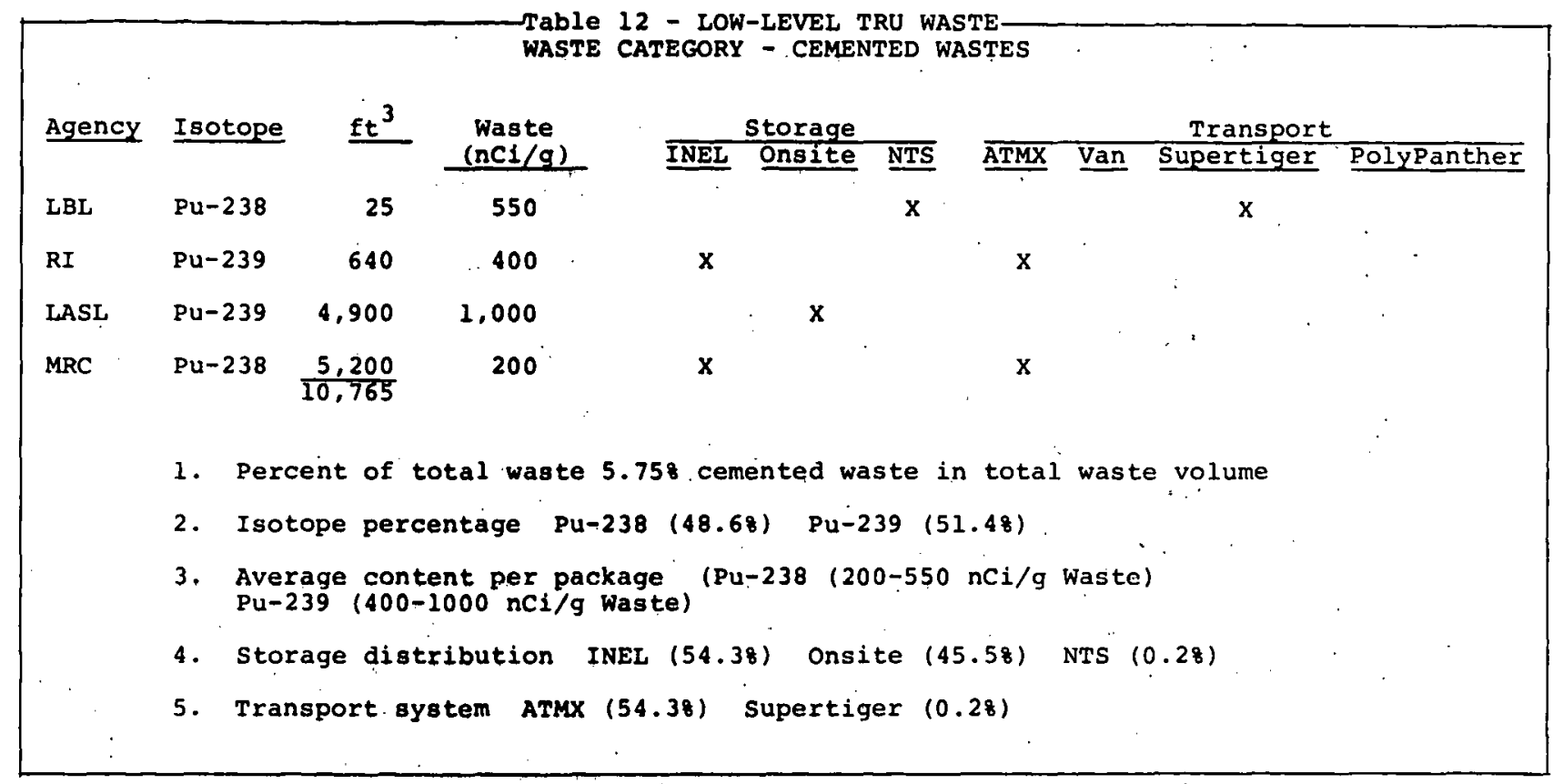

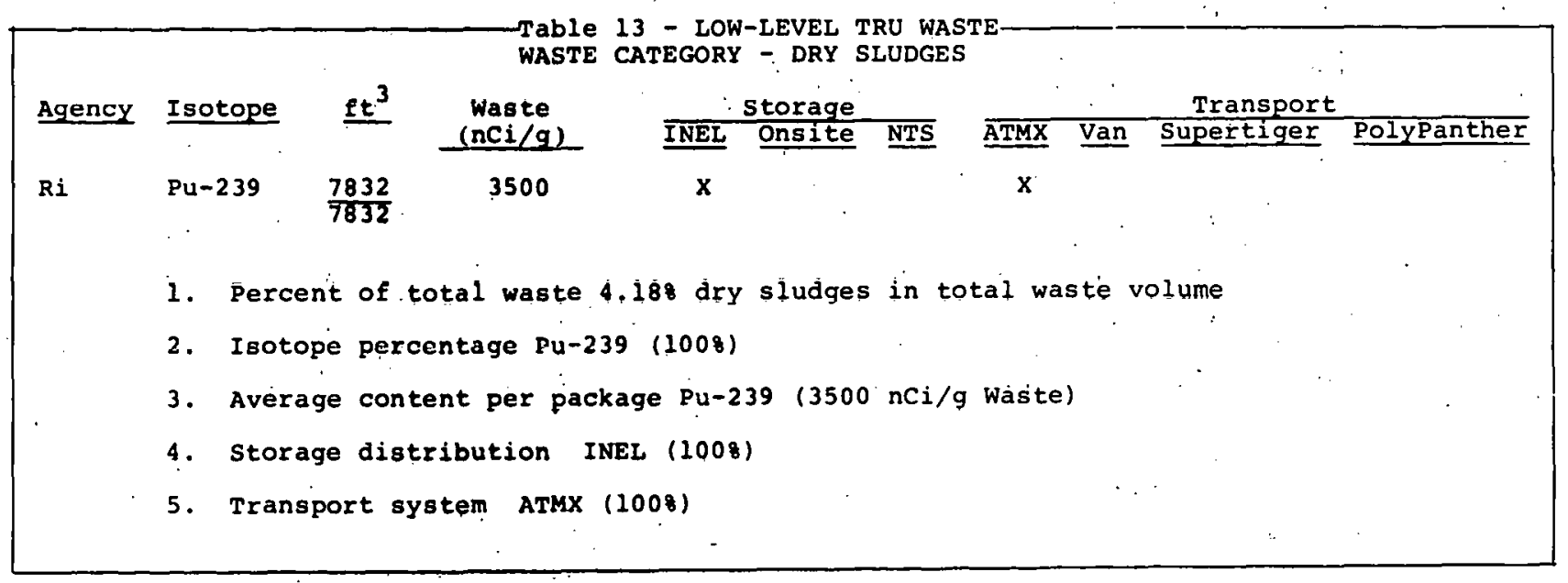




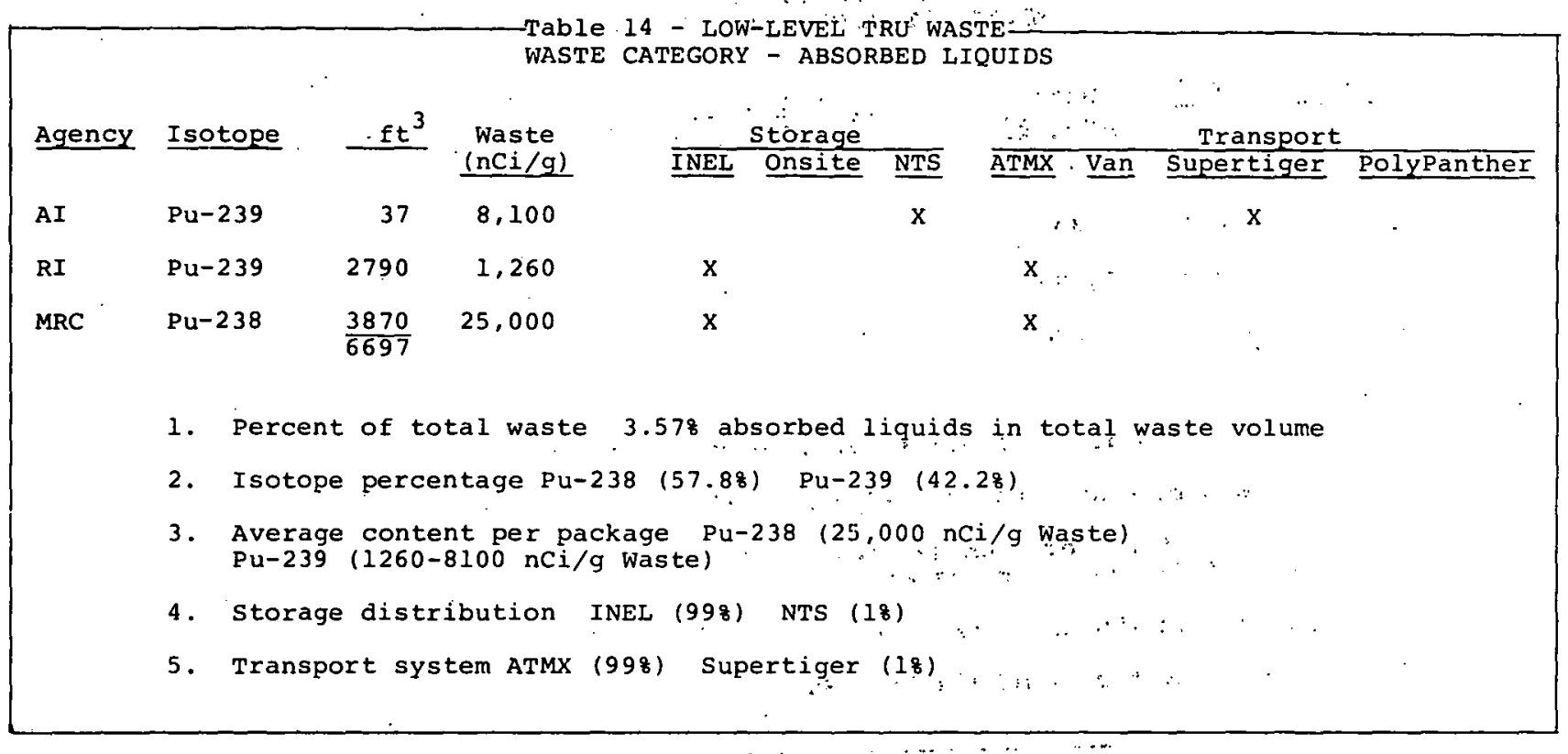

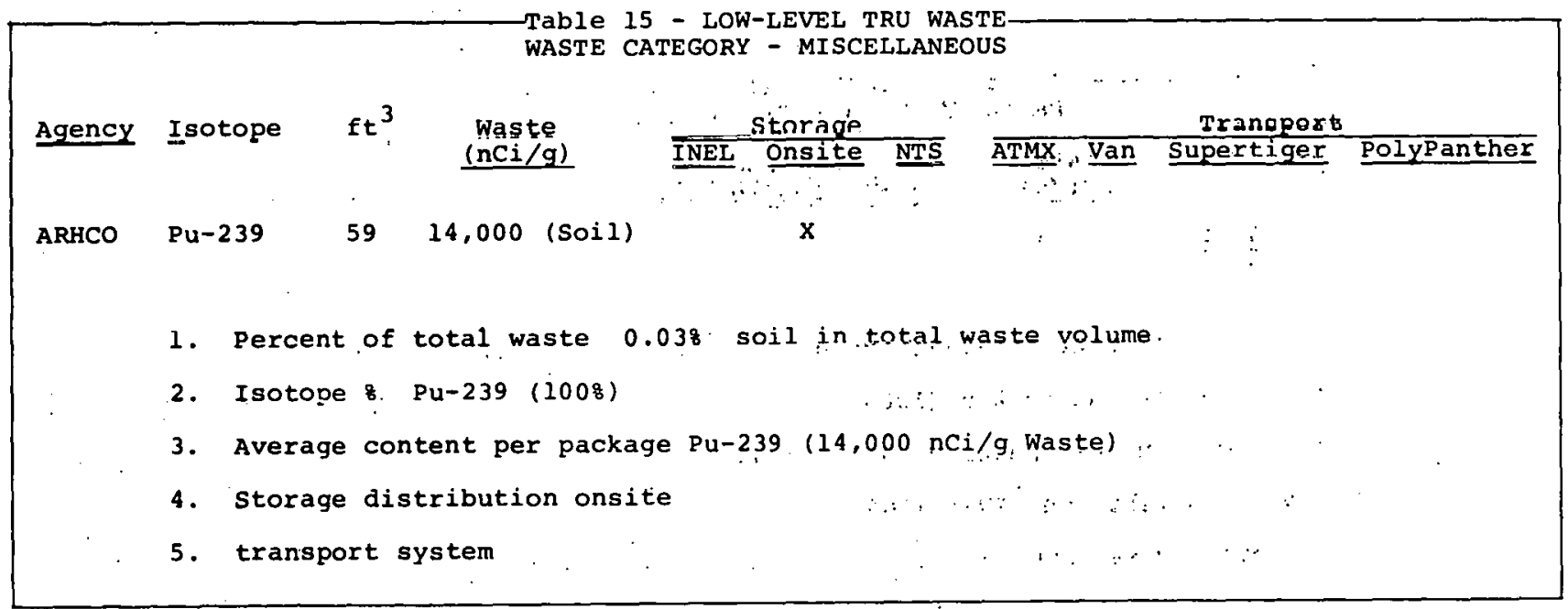


On June 2, 1977, MRC hosted a low-level TRU ERDA waste packaging meeting at Mound Laboratory. The meeting was attended by representatives of LASL, SLA, and OWI; it provided the opportunity for each representative to share pertinent packaging information and data in a form which was most useful in establishing preliminary TRU container acceptance criterion for application in both interim storage and terminal isolations. The results of this meeting are included in Appendix II.

\section{Basic application checklist}

The basic application checklist (Tables 16 and 17) was completed after receiving the waste packaging questionnaires from the ERDA waste generators and subsequent site visit follow-up for additional information. The checklist was developed to compile the low-level TRU waste shipping and storage containers for interim and onsite storage; it has 16 different packaging configurations currently in use for TRU waste storage. Plywood boxes covered with fiberglass-reinforced plastic and metal drums account for 928 of the total waste placed in interim storage for FY76-76A. The checklist includes the approximate total waste volumes $\left(\mathrm{ft}^{3}\right)$ stored in each packagc oonfiguration. The configurations vary due to onsite storage environments, limited size-reduction facilities, lack of standards, and costs. Wastes packaged as noncombustibles inside metal drums (checklist items 1 thru 7) and metal bins (item 14) could be readily acceptable to the terminal isolation facility. The remaining packaging configurations will be required to meet DOT shipping regulations or be shipped inside a reusable overpack meeting DOT shipping regulations. The configurations must also meet the design specifications of the terminal isolation facility which presently include, but are not limited to size, weight, of combustible, and handling.

\section{Survey of container manufacturers}

A survey of container manufacturers was initiated in June 1977 to determine if any commercially available containers are applicable to the shipment and storage of low-level TRU waste. The survey will provide an overview of current packaging technology and availability. A marketing information center has supplied a mailing list of 4191 National Manufacturers in seven major container categories who are currently engaged in the manufacture of containers used for packaging and shipment of various industrial commodities. The manufacturers will be contacted by mail and invited to submit. technical information on: container types; size, shápe, Internal volume; welght; closures; DOT certification (if applicable); performance data; unit and quantity cost. 
Package

Number

1

2

3

4

5

6

7

8

9

10

11

12

13

14

15

16

\section{TRU IOW-Level Waste Package Description}

55-gallon steel drum, DOT 17H, zinc dipped, polyethylene $(\mathrm{PE})$ bag liner

55-gallon steel drum, DOT $17 \mathrm{H}$ interior and exterior painted, PE bag liner

55-gallon stainless steel drum, DOT 17H, PE bag. liner

55-gallon steel drum, DOT 17C, interior and exterior pàinted, $\mathrm{PE}$ bag liner

55-gallon steel drum, DOT 17C interior and exterior painted, $90 \mathrm{mil}$ high density polyethylene (HDPE) liner when lead sheilded $\$ 60.00$ additional

55-gallon steel drum, DOT 17C zinc dipped, 90 mịl HDPE liner

30-gallon stainless steel drum, PE bag liner.

30-gallon steel drum, interior and exterior painted

$\mathrm{PE}$ bag liner, 2 each inside concrete cask

Corrugated metal pipe, zinc dipped, 2 1/2". diameter

$x 20$ ' long

55-gallon steel drum, zinc dipped, $90 \mathrm{mil}$ HDPE.liner, inside concrete culvert

Welded steel box, 1/8" thick, PE bag liner, random sizes, will fit inside supertiger

Fiberglass reinforced polyester (FRP) plywood box, $4^{\prime} \times 4^{\prime} \times 7^{\prime}$, PE bag liner

FRP plywood box, random sizes, PE bag liner

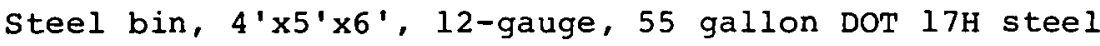
drums or 1/2" thick plywood box placed inside

FRP plywood box, random, steel drums inside

FRP plywood boxes, cold rolled steel boxes, inside

concrete culvert
Vol.ume

$\mathrm{ft} 3 / \mathrm{m}^{3}$

Approx.

Unit

Cost

7.42

$\$ 32.00$

0.21

7.42

$\$ 34.00$

0.21

7.42

$\$ 135.00$

0.21

7.42

$\$ 20.00$

0.21

. 7.42

0.21

$\$ 60.00$

7.42

$\$ 60.00$

0.21

4.01

$\$ 70.00$

0.11

8.02

$\$ 300^{\circ} .00$

0.22

98

2.78

7.42

$\$ 60.00$

0.21

Random $\$ 1000.00$

112

3.17

$\$ 400.00$

$\$ 800.00$

$8-1500$

$\$ 100.00$

.23-43

$\$ 1000.00$

120

$\$ 500.00$

3.40

Random

$\$ 2900.00$

Random

$\$ 1320.00$

$\$ 8000.00$ 
Package

Numbers

1

2

3

$4 \mathrm{x}$

5

6

7

8

9

10

11

12

$\mathrm{X}$

$\mathrm{X}$

$\mathrm{x}$

$\mathrm{x}$

$\mathrm{X}$

$\mathbf{X}$

$\mathrm{X}$

X $\mathrm{X}$

Total Volume

Per Waste

Package Type

$1430 \mathrm{ft}^{3}$ $40.5 \mathrm{~m}^{3}$

42]. $\mathrm{ft}^{3}$

$11.9 \mathrm{~m}^{3}$

$1925 \mathrm{ft}^{3}$

$54.5 \mathrm{~m}^{3}$

$14561 \mathrm{ft}^{3}$

$412.4 \mathrm{~m}^{3}$

$23314 \mathrm{ft}^{3}$
$660.3 \mathrm{~m}^{3}$

$3000 \mathrm{ft}^{3}$ $85.0 \mathrm{~m}^{3}$

$1925 \mathrm{ft}^{3}$

$54.5 \mathrm{~m}^{3}$

$800 \mathrm{ft}^{3}$

$22.7 \mathrm{~m}^{3}$

$4500 \mathrm{ft}^{3}$

$127.4 \mathrm{~m}^{3}$

$2000 \mathrm{ft}^{3}$

$56.6 \mathrm{~m}^{3}$

$1500 \mathrm{Et}^{3}$

$42.5 \mathrm{~m}^{3}$

$79700 \mathrm{ft}^{3}$

$2257.2 \mathrm{~m}^{3}$

$2000 \mathrm{ft}^{3}$

$56.6 \mathrm{~m}^{3}$

$4700 \mathrm{ft}^{3}$

$133.1 \mathrm{~m}^{3}$

14

$x$

15

$\mathrm{X}$

$43368 \mathrm{ft}^{3}$

$1228.2 \mathrm{~m}^{3}$

$2000 \mathrm{ft}^{3}$

16

$\mathrm{X}$

Total Volume 
THIS PAGE

\section{WAS INTENTIONALLY \\ LEFT BLANK}




\section{Appendix II}

Waste packaging meeting 
Mr. Robert Lowery

U. S. Energy Research and

Development Administration

Post Office Box. 5400

Albuquerque, New Mexico 87115

Dear Mr. Lowery:

On Thursday, June 2, 1977, a meeting was held at Mound Laboratory, Miamlsburg, OhIo, for the specific purpose of discussing proposed. criteria for an acceptable TRU waste package for application in both interim storage and terminal isolation. A list of meeting attendees 18 shown in Attachment $I$.

Based on conversations and personal contacts with waste generators on our recent site visits, the agenda for the meeting was

established (Attachment II), which provided the initial thrust for examining and discussing specific differences in the Wipp Criteria (Attachment III) and feelings shared by the contractors in relation to the criteria (Attachment IV).

The topics covered during the meeting stimulated interesting discussions by all attendees, and, after thoroughly reviewing each point with avallable factual data, a proposed, agreed upon definition and/or criterla acceptance was established (Attachment $V$ ) by the attendees. As you will notice, a definition for Low Level TRU Waste was proposed as was an associated definition of acceptable dose rate. These establish criteria for design of low level TRU waste containers. Combustibles were also defined. Under the proposed definition, the Fiberglass-reinforced Polyester Plywood Box (FRP) qualifies as a noncombustible package system. 
All generators of low level TRU waste expressed concern about the packaging of combustible (hydrogenous) materials. A definition of Gas Generating Materials was proposed, which will permit packaging of hydrogenous solid waste in noncombustible containers under the restrictions of 0.0695 curies/liter of total TRU isotope concentration per volume of the waste container. At this concentration, gas generation (radiolysis) in the short term (20120 yrs.) will not cause any terminal isolation facility pressure problems. This value may increase as additional experimentation is completed to provide factual documentation on the behavior of low level TRU waste in the salt environment.

Other decisions were proposed and adopted at the meeting as noted in Attachment $V$, however; the most important are those previously described. A complete composite of the entire meeting should be available for transmittal within the next few weeks, and will provide you with the specific infornation upen which these proposals were adopted.

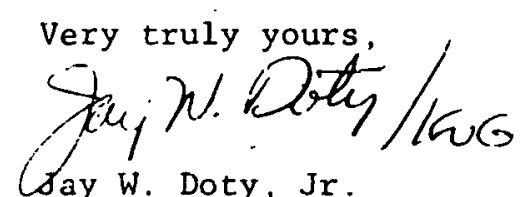

JWD : wd

Attachments

cc: G. H. Daly, ERDA/DWPR

R. Glenn Bradley, ERDA/DWPR

B. L. Kelchner, Rockwell International 


\section{ATTACHMENT I}

Attendees

TRU PACKAGING MEETING

Mound Laboratory

June 2, 1977

$\begin{array}{lll}\text { James D. Anderson } & \text { ARHCO } & \text { FTS 444-2670 } \\ \text { H. A. Zweifel } & \text { ARHCO } & \text { FTS 444-2840 } \\ \text { Gerald Maestas } & \text { LASL } & \text { FTS 843-7391 } \\ \text { Dean Nelson } & \text { LASL } & \text { FTS } 843-7391 \\ \text { John L. Warren } & \text { LASL } & \text { FTS 843-7391 } \\ \text { Paul o'Brien } & \text { Sandia } & \text { FTS 475-9160 } \\ \text { Bert Blanke } & \text { ERDA/DAO } & \text { FTS-774-3486 } \\ \text { Dick Blauvelt } & \text { Mound } & \text { FTS 774-3698 } \\ \text { J. W. Doty } & \text { Mound } & \text { FTS 774-3296 } \\ \text { Joseph M. Garner } & \text { Mound } & \text { FTS 774-3465 } \\ \text { Keith Gilbert } & \text { Mound } & \text { FTS 774-7239 } \\ \text { Bernie Kokenge } & \text { Mound } & \text { FTS 774-3581 } \\ \text { Howard Kreider } & \text { Mound } & \text { FTS 774-3309 } \\ \text { Marshall Ledford } & \text { Mound } & \text { FTS 774-3230 } \\ \text { Bruce Peterson } & \text { Mound } & \text { FTS 774-7288 }\end{array}$




\section{ATTACHMENT II \\ AGENDA \\ IOW IEVEL TRU WASTE PACKAGE \\ PRELIMINARY CRITERIA}

June 2,1977

OS -206
A. Welcome
B. Definition of Low-Level Waste
C. Dose Rate - Maximum Acceptance Value
D. Isotope Restriction in Combustible waste
E. Combustible Percent in Package Material of Construction
F. Fire Retardants - Flame Spread
G. Absorbed Liquids
H. Packaging Criteria - Short Term Until 1983
Long Term 1983 - On
I. Waste Currently stored
1. Relationship to above problems
2. Percentage of INEL waste that would be acceptable under conditions above
J. WIPP Retrievable Concept - Time Period
K. : closing Remarks 


\section{DEFINITIONS}

\section{A. Low-Level TRU Waste}

Any solid waste material, other than high-level. waste which is contaminated with long-lived alpha emitters to the extent that, under the provisions of ERDAM Chapter 05li, it is not suitable for surface burial, but which exhibits sufficiently low radiation levels that it is amenable to handling by "contact" (as opposed to remote) methods.

B. Dose Rate

The dose rate from penetrating radiation at the surface of an individual waste package may not exceed $500 \mathrm{millirem} / \mathrm{hr}$ averaged over the waste packages in a given shipment, the surface does rate may not exceed $200 \mathrm{millirem} / \mathrm{hr}$.

C. Restriction in Combustible Waste

\section{Combustibles}

For the purpose of these criteria combustibles are defined as those materials which can be ignited in 15 minutes or less when exposed to a temperature of $1300^{\circ} \mathrm{F}\left(700^{\circ} \mathrm{C}\right)$ in atmospheric air. The intent of this definition is to differentiate readily incinerable materials (such as graphite) which can be incinerated only by extraordinary means.

(GAS GENERATION)

(PYROLYSIS)

2. Combustible Percent in Package Material of Construction.

Waste shipments to the WIPP will; be coordinated on an ERDA-wide basis so that the total amount of combustibles stored in a single storage room does not exceed $20 \%$ by volume. In the context of this criterion, the wood used

in the fabrication of DOT 19A and similar containers is considered to be combustible.

D. Fire Retardants-Flame spread

Measures which can be taken to reduce fire hazards:

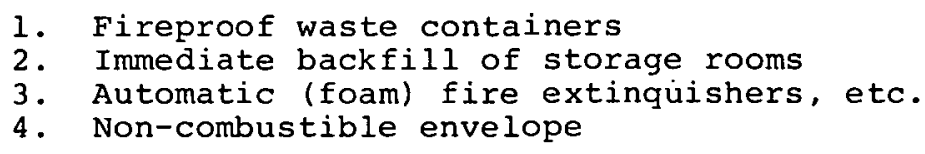

E. Adsorbed Liguids

Waste-containing free liquids will not be accepted for storage at the WIPP. Process sludges must either be dried by heating or mixed homogeneously with an appropriate drying agent; in either case, the liquid of the product should be limited to that required to minimize dispersal of the waste in a handling accident. 


\section{G. Additional Discussion Topics}

1. Packaging Criteria -

a. Short-Term until 1983

b. Long-Term 1983 - on

2. Waste currently stored

a. Relationship to above problem $\because \cdots \quad \cdots \quad \cdots \quad \cdots$

b. Percentage of INEL waste that would be acceptable under conditions above

3. WIPP retrievable concept-time period

4. Closing remarks 


\section{ATTACHMENT IV}

\section{CONTRACTOR OPINION OF CRITERIA}

\section{DEFINITIONS}

\section{A. Low-Level TRU Waste}

Wastes contaminated with TRU nuclides to levels greater than the proposed level of lonci of alpha activity per gram of waste, requiring no shielding for personnel protection, with radiation levels less than $500 \mathrm{milli}$ rem/hr'measured at the package surface.

B. Dose Rate

\section{Common Carrier}

a. All radioactive materials must be packaged in suitable packaging (shielded if necessary) so that at any time during the normal conditions incident to transportation the radiation dose rate does not exceed $200 \mathrm{millirem} / \mathrm{hr}$ at any point on the external surface of the package and $10 \mathrm{millirem} / \mathrm{hr}$ at three feet.

b. Sole Use Vehicle

i. $1000 \mathrm{millirem} / \mathrm{hr}$ at 3 feet from the external surface of the package (closed transport vehicle only);

ii. $200 \mathrm{millirem} / \mathrm{hr}$ at any point on the external surface of the car or vehicle' (closed transport vehicle only);

iii. $10 \mathrm{millirem} / \mathrm{hr}$ at 6 feet from the external surface of the car or . vehicle; and

iv. $2 \mathrm{millirem} / \mathrm{hr}$ in any normally occupied position in the car or vehicle, except private carriers.

C. Isotope Quality Restrïtion in Combustible Waste

Hydrogenous waste packaged in a 210 liter drum (550gallon Dot 17c), FRP Box, etc., will contain less than 0.0695 curies/liter of TRU isotope.

(GAS GENERATION)

D. Combustible Percent in Package Material Construction

Date indicate that the fiberglass reinforced $19 \mathrm{~A}$ boxes will self extinguish after 15 minutes at $700^{\circ} \mathrm{C}$ in air.

\section{E. Fire Retardants-Flame spread}

1-4 agreement with terminal criteria

F. Absorbed Liquids

Will WIPP accept acids, caustics, organics (oils)? 
ATTACHMENT V

PROPOSED DEFINITIONS

Consensus of Meeting Attendees

\section{DEFINITIONS}

A. Low-Level TRU Waste

Any solid waste material, other than high activity waste, which is contaminated with long-lived apha emitters to the extent that, under the provisions of ERDAM 05ll, it is not suitable for surface burial and which exhibits a maximum of 500 $\mathrm{millirem} / \mathrm{hr}$ surface dose rate.

B. Dose Rate

The dose rate from penetrating radiation at the surface of an individual waste package may not exceed $500 \mathrm{millirem} / \mathrm{hr}$. The surface dose rate may not exceed $200 \mathrm{millirem} / \mathrm{hr}$ averaged over the waste packages in a transport vehicle.

C. Combustibles and Gas Generating Materials

\section{Combustibles}

For the purpose of these criteria combustibles are defined as those materials which will sustain combustion when exposed to a temperature of $1300^{\circ} \mathrm{C}\left(700^{\circ} \mathrm{C}\right)$ for 15 minutes or less in atmospheric air. The intent of this definition is to differientiate readily incinerable materials (such as paper, plastics, and pyrophoric materials) from materials (such as graphite) which can be incilerated. only by extraordinary means.

2. Gas Generating Materials

Packaged hydrogenous waste will be limited to a maximum of 0.0695 curies/1iter of total TRU isotope concentration per volume of the waste container.

D. Combustible Percent in Package Material of Construction

The first portion of this definition could not be related or discussed since it affects the long-term storage problems associated with terminal isolation storage. The percent value will be established after experimentation is completed which will provide information on gas generation (corrosive effect of the salt on containers), toxicity and gas permeation. A standard DOT 19A wooden box is combustible by the definition proposed, however, the FRP box by the proposed definition is now agreed to be a noncombustible container.

E. Pire Retardanta-Flame Eprcad

No agreement was achieved in relation to this criterion. It was suggested that operations in the isolation facility be designed and implemented to reduce fire hazards to the minimum risk level. Also, engineering and construction design should be considered to reduce to the minimum risk level the possibility of water intrusion into the mine during the operation phase (35-40 years) and for long-term storage.

\section{F. Adsorbed Liquids}

Concrete wast.e forms cannot be excluded from storage in the isolation facility, primarily due to the quantity of this waste form already generated and stored in an interim mode. Adsorbed liquids will also be permitted, provided the waste form is totally adsorbed and the package contains no free liquids. Acid and caustic solutions were not addressed by the WIPP criteria, but the work group proposed that both acid and caustic liquid wastes be neutralized to reduce the corrosion of the waste container. If neutralized and solidified, other alternative packaging systems could be considered; e.g.. elimination of the High-Density Polyethylene liners. 
In relation to the subjects of explosives, pyrophorics, and toxic agents in the waste, the working group proposed that the WIPP criteria state that the generators ensure through administrative operating controls that each of these items be eliminated from the packaged low-level TRU waste containers. The TRU Packaging Questionnaire data supports the fact that generators are not packaging explosives, pyrophorics, or toxic materials in their waste.

G. Additional Disucssion Topics

\section{Package Criteria}

\section{Short-Term Versus Long-Term Problems}

At the present time, generators of waste are in a middle situation being bound by ERDAM 0511 (intact, contamination-free for 20-year retreivability) and INEL interim storage criteria. These constraints are not required for terminal isolation, and therefore, waste packages presently used to meet interim will impose an economic disadvantage to the generator over the next $3-5 \mathrm{yr}$.

It was proposed at the meeting that data are required to characterize material types generally acceptable for construction of waste packaging containers. The materials (metal, plastic, fiberglass, fiberboard, etc.) could then be evaluated on the basis of gas generation, general strength, thermal effects, corrosion in salt, chemical resistivity and other properties in relation to significant storage parameters. Mound Laboratory will perform this study utilizing LAsL and RFP data as part of the TRU Packaging study. OWI is sponsoring a similar study for commercial waste and information can also be extracted from their efforts in container-type acceptability.

2. This item was eliminated from discussion because of the Task Force assigned to examine these parameters.

3. WIPP criteria do not specify the time of the retrievable mode concept. SLA posj.tion is that $5 \mathrm{yr}$ is maximum for determining how the low-level TRU waste will behave in the salt environment. 


\title{
Distribution
}

\author{
EXTERNAL \\ TIC, UC-70 (267) \\ W. A. Brobst, ETC \\ J. A. Chacon, DoE/DAO (2) \\ R. I. Chitwood, DOE/DWMPR (2) \\ D. Davis, DoE/ALO (2) \\ R. K. Flitcraft, . MRC \\ T. C. Jones, DOE/ALO \\ D. W. King, DOE/ALO (2) \\ R. Y. Lowery, DOE/ALOO \\ G. Oertel, DoE/DWPR
}

\section{INTERNAL}
A. G. Barnett
W. H. Bond
W. T. Cave
J. W. Doty (16)
D. A. Edling
J. M. Garner
K. V. Gilbert
L. V. Jones
J. W. Koenst
B. R. Kokenge
D. L. Luthy
J. R. McClain
J. B. Peterson
L. B. Stevens
R. E. Vallee
H. L. Williams
Library (15)
Publications 